\title{
Very high genetic fragmentation in a large marine fish, the meagre Argyrosomus regius (Sciaenidae, Perciformes): impact of reproductive migration, oceanographic barriers and ecological factors
}

\author{
Pierrick HAFFraY ${ }^{1, a}$, Rachid MALHA ${ }^{2}$, Mahfoud OUld TAleb SIDI ${ }^{3}$, Nuno PRISTA $^{4}$, Moshira HassaN $^{5}$, \\ Gérard CASTELNAUD ${ }^{6}$, Bilge KARAHAN-NOMM ${ }^{7}$, Kutsal GAMSIZ ${ }^{7}$, Sherif SADEK ${ }^{8}$, \\ Jean-Sébastien BRUANT ${ }^{9}$, Philippe BALMA ${ }^{10}$ and François BONHOMME ${ }^{10}$ \\ 1 SYSAAF, Station SCRIBE/INRA, Campus de Beaulieu, 35042 Rennes, France \\ 2 LABOGENA, INRA, Domaine de Vilvert, 78350 Jouy-en-Josas, France \\ 3 IMROP, BP 22, Nouadhibou, Mauritania \\ 4 Centro de Oceanografia, Faculdade de Ciências da Universidade de Lisboa, Campo Grande, 1749-016 Lisboa, Portugal \\ 5 Reef Check, Wachmannstr. 25, 28209 Bremen, Germany \\ ${ }^{6}$ IRSTEA (ex-CEMAGREF), 50 av. de Verdun, 33612 Cestas, France \\ 7 Ege University, Fisheries Faculty, Aquaculture Dep., 35100 Izmir, Turkey \\ 8 FMD, BP 4, 17840 La Brée les Bains, France \\ 9 Les Poissons du Soleil, BP 10, 34540 Balaruc-les-Bains, France \\ ${ }^{10}$ CNRS UMR 5554, Institut des Sciences de l'Evolution, Université de Montpellier II, 2 rue des Chantiers, 34200 Sète, France
}

Received 5 April 2011; Accepted 8 June 2012

\begin{abstract}
The meagre Argyrosomus regius is a large Sciaenid fish known to reproduce in the eastern Atlantic and Mediterranean Sea in just five distinct and restricted geographic areas: along the Mauritanian coast and at estuary openings (Gironde, Tagus, Guadalquivir and Nile). The biological traits of A. regius (high dispersal capabilities, high fecundity, long larval phase, overlapping generations, reproduction until 40 years of age) are, in principle, favourable to high gene flow, which should lead to genetic homogeneity over large geographic scales. Nevertheless, the high geographic distances between the few reproductive areas leads one ask whether there is genetic differentiation in this species. In the present study, the genetic differentiation of the wild A. regius was investigated across most of its natural range from the Atlantic Ocean (France, Portugal, Spain, Mauritania) to the Mediterranean Sea (Egypt, Turkey), using 11 microsatellite markers previously identified in another Sciaenid, the red drum Sciaenops ocellatus. At least two very distinct groups could be identified, separated by the Gibraltar Strait. Genetic divergences ( $F_{\text {ST }}$ values) were intermediate between the Atlantic samples (0.012-0.041), high between Egypt and the Atlantic (0.06-0.107) or Aegean Sea (0.081) and extremely high between the Aegean Sea and the Atlantic (0.098-0.168). A. regius exhibited a very high level of genetic differentiation rarely reported in marine fishes. These results also demonstrate the existence of a sixth independent spawning area in the Menderes delta (Turkey). Factors potentially involved in this very high genetic fragmentation are discussed, including physical barriers, glaciation pulses and biological traits.
\end{abstract}

Keywords: Genetic variation / Population differentiation / Linkage disequilibrium / Microsatellites / Sciaenids / Drum / Umbrina / Pseudotolithus / Argyrosomus

\section{Introduction}

Marine fishes generally exhibit limited genetic differentiation across large geographic distances $(>1000 \mathrm{~km})$. This pattern has been attributed to their high rates of dispersal and movement during both nektonic and planktonic phases

a Corresponding author: haffray@rennes.inra.fr
(Gyllensten 1985; Ward et al. 1994). The level of withinspecies differentiation also depends on physical or biological barriers such as hydrology, oceanic fronts, geomorphology, historical sea-level variation and animal behaviour, which interact with complex species-specific life history traits. Therefore, within-species differentiation is difficult to predict even if such pattern is known for other closely related conspecific or confamilial species (Naciri et al. 1999; Patarnello et al. 2007). 
Table 1. Description of the twelve Argyrosomus regius collection sites by geographic origin, locality, coordinates, abbreviation, size, date of collection, mean standard body length $(\mathrm{cm} \pm \mathrm{SD})$, known or estimated (in bracket) age according to Hermas (1995), and origin (Exp: experimental fishery; Fishery: at fisheries landings; Aquac: from aquaculture of wild fish).

\begin{tabular}{|c|c|c|c|c|c|c|c|c|}
\hline Geographic origin & Locality & Coordinates & Abbreviation & $N$ & $\begin{array}{l}\text { Date of } \\
\text { collection }\end{array}$ & $\begin{array}{l}\text { Standard body } \\
\text { length }(\mathrm{cm})\end{array}$ & $\begin{array}{l}\text { Age } \\
\text { (years) }\end{array}$ & Origin \\
\hline \multirow{9}{*}{ Atlantic Ocean } & Gironde estuary, Mortagne, France & $45^{\circ} 27^{\prime} \mathrm{N}, 52^{\circ} 34^{\prime} \mathrm{W}$ & France-1 (F1) & 35 & 25 June 2008 & $19.8 \pm 2.2$ & 2 & \multirow{2}{*}{ Exp } \\
\hline & $\begin{array}{l}\text { Gironde estuary, St Seurin sur } \\
\text { Dizet, France }\end{array}$ & $45^{\circ} 29^{\prime} \mathrm{N}, 55^{\circ} 23^{\prime} \mathrm{W}$ & France-2 (F2) & 37 & 26 June 2008 & $35.6 \pm 1.2$ & 3 & \\
\hline & $\begin{array}{l}\text { Tagus estuary and Peniche, } \\
\text { Portugal }\end{array}$ & $39^{\circ} 21^{\prime} \mathrm{N}, 9^{\circ} 22^{\prime} \mathrm{W}$ & Portugal-1 (P1) & 37 & $\begin{array}{l}\text { Sept. } 2005 \text { to } \\
\text { May } 2007\end{array}$ & $83.3 \pm 30.9$ & $2-12$ & \multirow[t]{2}{*}{ Fishery } \\
\hline & South coast (Algarve), Portugal & $37^{\circ} 11^{\prime} \mathrm{N}, 7^{\circ} 24^{\prime} \mathrm{W}$ & Portugal-2 (P2) & 30 & $\begin{array}{l}\text { Aug. } 2005 \text { to } \\
\text { Jan. } 2007\end{array}$ & $84.9 \pm 40.5$ & $2-23$ & \\
\hline & Guadalquivir estuary, Spain & $36^{\circ} 57^{\prime} \mathrm{N}, 6^{\circ} 14^{\prime} \mathrm{W}$ & Guadalquivir (S1) & 30 & 9 Febr. 2009 & $\begin{array}{l}\text { Data not } \\
\text { available }\end{array}$ & 4 & Aquac \\
\hline & Nouakchott, Mauritania & $18^{\circ} 06^{\prime} \mathrm{N}, 16^{\circ} 01^{\prime} \mathrm{W}$ & Mauritania-1 (M1) & 12 & 19 May 2008 & $142 \pm 8$ & $(>15)$ & \multirow{4}{*}{ Fishery } \\
\hline & Nouadibou, Mauritania & $20^{\circ} 54^{\prime} \mathrm{N}, 17^{\circ} 02^{\prime} \mathrm{W}$ & Mauritania-2 (M2) & 9 & 21 May 2008 & $139 \pm 13$ & $(>14)$ & \\
\hline & Nouamghar, Mauritania & $19^{\circ} 21^{\prime} \mathrm{N}, 16^{\circ} 30^{\prime} \mathrm{W}$ & Mauritania-3 (M3) & 12 & 22 May 2008 & $145 \pm 13$ & $(>14)$ & \\
\hline & Arkais, Mauritania & $20^{\circ} 07^{\prime} \mathrm{N}, 16^{\circ} 15^{\prime} \mathrm{W}$ & Mauritania-4 (M4) & 29 & 23 May 2008 & $83 \pm 15$ & $(>6)$ & \\
\hline Eastern & Port Said (Farm 1), Egypt & $31.21^{\prime} \mathrm{N}, 32^{\circ} 02^{\prime} \mathrm{E}$ & Egypt-1 (E1) & 30 & 12 Oct. 2009 & $28.5 \pm 2.9$ & 0 & \multirow{2}{*}{ Aquac } \\
\hline Mediterranean Sea & Menderes Delta, Turkey & $37.32^{\prime} \mathrm{N}, 27^{\circ} 10^{\prime} \mathrm{E}$ & Turkey (T1) & 30 & 7 March 2009 & $115 \pm 10$ & 10 & \\
\hline
\end{tabular}

The meagre Argyrosomus regius (Asso 1801) is one of the world's largest Sciaenids, attaining over $180 \mathrm{~cm}$ total length and $50 \mathrm{~kg}$ body weight (after FishBase.org). This coastal semipelagic species is distributed in the eastern Atlantic Ocean, from the Bay of Biscay to the coast of Senegal, and across the Mediterranean Sea, Black Sea and Gulf of Suez. Planktonic eggs (990 $\mu \mathrm{m}$ diameter) are spawned in open water and hatched within $48 \mathrm{~h}$. Mouth opening is observed 2-3 days post hatch and yolk sac absorption within 7 days post hatch (Tixerant 1974). Planktonic larvae develop in shallow lagoons and over mudflats when the temperature exceeds $20^{\circ} \mathrm{C}$ (Quéro and Wayne 1987). Juveniles migrate and spread toward deeper waters in their second year $\left(60-200 \mathrm{~m}, 12{ }^{\circ} \mathrm{C}\right)$. The reproductive biology of $A$. regius combines several specific reproductive traits (Tixerant 1974; Quéro and Vayne 1987; Hermas 1995; Prista et al. 2009). Adults migrate to coastal reproductive areas (10-15 $\mathrm{m}$ deep with high water flow associated with estuaries and/or tides) to spawn when temperatures reach 13 to $23{ }^{\circ} \mathrm{C}$. The species exhibits also very high fecundity, late first reproduction (7 years old), long generation interval ( $>40$ years), overlapping generations, aggregation and schooling migration in nearshore waters. More over, only five restricted coastal spawning areas have been documented to date in the Lévrier Bay and the Banc d'Arguin (Mauritania) and at the opening of the Gironde (France), the Tagus (Portugal), the Guadalquivir (Spain) and the Nile (Egypt) estuaries (Tixerant 1974; El-Hehyawi 1974; Costa 1986; Quéro and Vayne 1987; Quéro 1989a, 1989b; GonzálezQuirós et al. 2011).

Most of the above-mentioned reproductive traits favour low or absent genetic differentiation, while the high geographic distances between the only five reproduction areas would act in the opposite direction. However, no genetic information has been reported to date for A. regius.

The objective of this study was thus to characterise the genetic variability of $A$. regius across its native range, using microsatellite nuclear markers previously isolated from another Sciaenid, the red drum Sciaenops ocellatus (Linnaeus 1766) by Renshaw et al. (2006). Two further Sciaenid species that live sympatrically with $A$. regius were also genotyped with the same markers to assess potential misidentification: the shi drum Umbrina cirrosa (Linnaeus 1758) sympatric in the Mediterranean Sea and the law croaker Pseudotolithus senegallus (Cuvier 1830) sympatric along the west coast of Africa. The results are expected to provide useful information for the preservation of wild stocks, improvements in fishery management and initiation of breeding programs for A. regius aquaculture.

\section{Materials and methods}

\subsection{Sample collection}

Fin clips from 378 wild A. regius were collected from twelve different locations in the Atlantic Ocean and eastern Mediterranean Sea (Table 1, Fig. 1) by experimental fishery (in F1 and F2) or obtained from catches landed by local fishermen (in P1, P2 and M1 to M4) or from fish farms rearing wild fish (S1, E1, E2, T1). Further information is given per site of collection:

1. Sites F1 and F2 (France): fish from two age groups (2 years of age for $\mathrm{F} 1$ and 3 years of age for F2) were captured in 2008 in the Gironde estuary at Mortagne (F1) and at St Seurin d'Uzet (F2) using the IRSTEA catamaran research vessel, L'Esturial equipped with a bottom trawl (mesh size: $40 \mathrm{~mm}$ ).

2. Site S1 (Spain): wild fish from 4 years of age were collected in 2008 in the FMD hatchery (Oléron Island, France). These fish were captured at 5-10 g in the Guadalquivir estuary in the summer 2005 by PIMSA fish farm (Seville, Spain).

3. P1 and P2 (Portugal): Fish came from two commercial landing areas located along the western (Tagus estuary and Peniche) and southern coasts (Quarteira to Vila Real de Santo António) of Portugal. Samples from both sites included juveniles and adults collected from 2005 to 2007. 


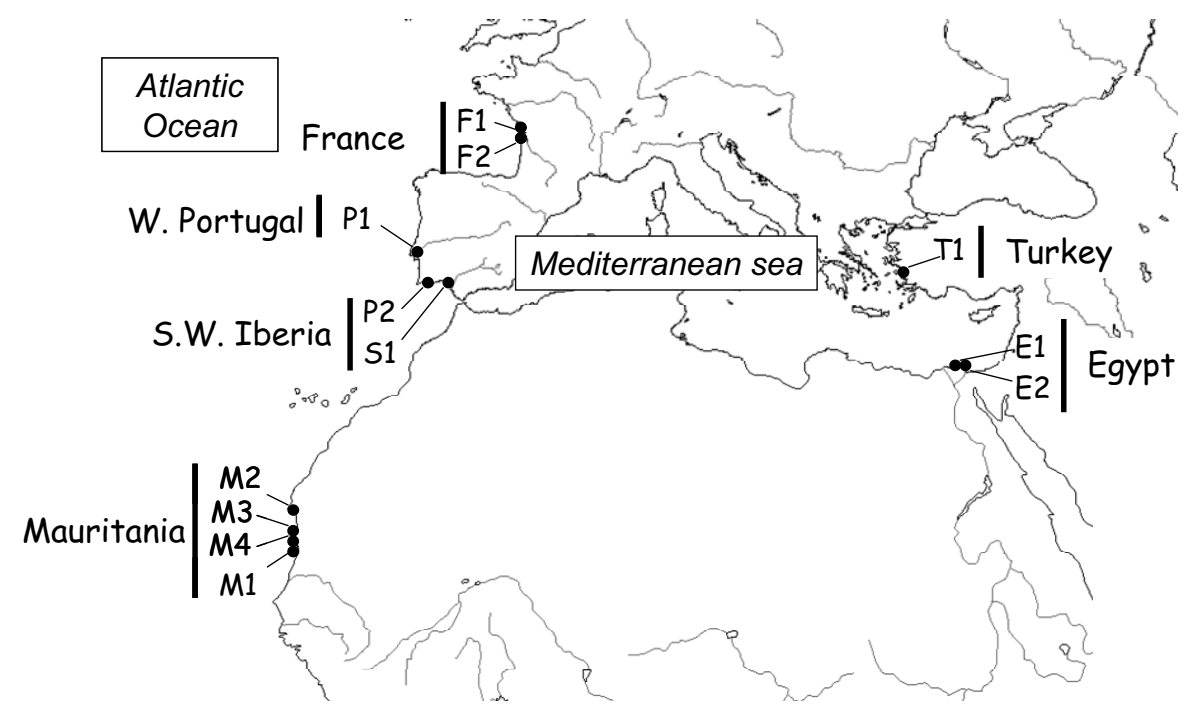

Fig. 1. Geographic locations of the twelve collection sites (abbreviations: F1, F2, etc.) and populations (full name: France, etc.) of meagre Argyrosomus regius samples. Abbreviations, localities and coordinates are given in Table 1.

4. Sites M1 to M4 (Mauritania): fins were collected in 2008 at commercial landing sites located at Nouakchott and Nouadhibou fishing harbours and in Nouamghar and Arkais Imragen villages (Parc National du Banc d'Arguin). The samples consisted of adult fish except in M4.

5. Sites E1 and E2 (Egypt): the samples were collected in 2009 from two fish farms located along the Manzalla Lake, close to Port Said. The fish consisted of wild juveniles captured as described by Sadek et al. (2009) between February and March 2008 along the Mediterranean coast between Alexandria and Port Said.

6. Site T1 (Turkey): fins were collected in 2009 from wild fish reared in captivity in the Egemar Su Ürünleri A.P. fish farm (Akbük-Didim, Aydın, Turkey). Fish consisted of mature individuals grown in the fish farm since their capture at 5-10 $\mathrm{g}$ in the lagoons of the Menderes Delta, south of Izmir during July and August 2000.

The shi drum (U. cirrosa) samples were collected in Turkey $(n=31)$ in the same geographical area as the A. regius samples. The law croaker ( $P$. senegallus) samples were collected in Mauritania in Nouadhibou $(n=14)$ and in Arkais $(n=3)$, on the same days as the $A$. regius samples.

\subsection{PCR amplification and microsatellite typing}

All samples were stored in 95\% alcohol and genotyped using 14 red drum microsatellites (Renshaw et al. 2006) combined to make two new panels: Soc11, Soc140, Soc400, Soc416, Soc423, Soc428, Soc592, Soc593 in panel 1 and Soc35, Soc44, Soc156, Soc410, Soc412, Soc432 in panel 2. Polymerase chain reaction (PCR) amplifications were performed in a final volume of $10 \mu$ l using a Qiagen ${ }^{\circledR}$ Multiplex PCR Kit and 50-100 ng of template DNA. Reactions were run for 30 cycles in an MJ thermal cycler (Model PTC-200). The PCR amplifications included an initial activation step at $95{ }^{\circ} \mathrm{C}$ for $15 \mathrm{~min}$, denaturation at $94{ }^{\circ} \mathrm{C}$ for $30 \mathrm{~s}$, primer annealing at
$60{ }^{\circ} \mathrm{C}$ for $90 \mathrm{~s}$, extension at $72{ }^{\circ} \mathrm{C}$ for $1 \mathrm{~min}$ and final extension at $60{ }^{\circ} \mathrm{C}$ for $30 \mathrm{~min}$. After PCR amplification, an applied biosystems 3730 xl DNA analyser with GeneMapper Analysis software (Applied Biosystems) was used to analyse the fluorescently tagged fragments for length polymorphisms.

\subsection{Data analysis}

\subsubsection{Genetic variability and departure from Hardy-Weinberg equilibrium}

The mean number of alleles per locus $(N A)$ and the observed $\left(H_{\text {obs }}\right)$ and unbiased expected $\left(H_{\text {exp }}\right)$ heterozygosity (Nei 1978) were computed for each collection site and locus using Genetix 4.05.2 (Belkhir et al. 2004). The departure of genotypic frequencies from the expectations of HardyWeinberg equilibrium (HWE) was estimated within each site by the inbreeding coefficient or Wright's fixation index $\left(F_{\text {IS }}\right)$ using Weir and Cockerham's (1984) $f$-estimator. The significance of the $F_{\text {IS }}$ greater than zero (i.e. consistency with the null hypothesis on HWE) was estimated after 10000 random allelic permutations and using simple Bonferroni procedure (Rice 1989) to correct for multiple testing and avoid type-1 errors (Rice 1989). In A. regius, the presence of null alleles or other scoring errors were estimated for all loci and collection sites using the MICRO-CHECKER program version 2.2.3 (van Oosterhout et al. 2004). The program uses the Monte Carlo simulation method to generate expected allele size difference frequencies and to compare the estimated null allele frequency using four different methods.

\subsubsection{Genetic differentiation between populations and phylogenetic relationships}

The differentiation between collection sites was estimated using Weir and Cockerham's (1984) global fixation index 
$\left(F_{\mathrm{ST}}\right)$ estimator. $F_{\mathrm{ST}}$ were computed between sites of collection using Genetix 4.05.2 (Belkhir et al. 2004). Study-wide significance levels across collection sites were adjusted using 10000 permutations on individual genotypes for the simple Bonferroni procedure.

The twelve collection sites were grouped into six new collection sites on the basis of the lack of significant pair-wise $F_{\text {ST }}$ values between some of them and to increase the number of fish per site to 50 as recommended by Ruzzante (1998). The Mauritanian sites were pooled and treated as one population because of the limited number of samples per collection site, their close geographic proximity and their lack of genetic differentiation (though M4 was significantly different from M3 it had no transitivity with M2 and M1). The six new collection sites were identified as: "Egypt" (E1 + E2), "France" (F1 + F2), "Mauritania" (M1 + M2 + M3 + M4), "Southwest Iberia" $(\mathrm{S} 1+\mathrm{P} 2)$, "West Portugal" (P1) and "Turkey" (T1). These groupings were used in all further analyses and comparisons.

The same genetic estimators $\left(H_{\mathrm{e}}, H_{\mathrm{obs}}, N A\right.$, number of alleles, number of fish genotyped, $\left.F_{\mathrm{IS}}, F_{\mathrm{ST}}\right)$ and statistical tests were then computed. Allelic richness $(A R)$, representing a measure of the number of alleles independent of the sample size, was estimated using Fstat 2.9.3.2. (Goudet 1995). Difference in mean allelic richness and heterozygosity among the 6 collection sites were estimated using Friedman non-parametric test. The phylogenetic tree was drawn in MEGA 4.0 (Tamura et al. 2007) based on the $D_{\text {Reynolds }}$ genetic distances and using the neighbour-joining algorithm (Saitou and Nei 1987).

Different methods exist to estimate effective population size $(\mathrm{Ne})$ based on heterozygote excess, temporal variation, linkage disequilibrium or the Bayesian method and can produce different results. As the estimation of $\mathrm{Ne}$ was not the main objective of the present work, estimation was only made based on non-random gametic linkage disequilibrium $(L D)$ using $L D N e$ software (Waples and Do 2008). Minimum allelic frequency was fixed at 0.05 , as the less biased frequency reported and putative $95 \%$ confidence intervals calculated with parametric or jackknife methods.

\section{Results}

\subsection{Genotyping of markers in each species}

- Pseudotolithus senegallus: three of the 14 genetic markers did not amplify (Soc35, Soc416, Soc428) and 4 markers were monomorphic (Soc140, Soc156, Soc400, Soc592). The last 7 markers could be amplified and had a maximum of 4 alleles per marker (Soc11, Soc44, Soc410, Soc412, Soc423, Soc432, Soc593). Soc410 exhibited 4 alleles not observed in $A$. regius. Four of the seventeen fish sampled did not amplify at any locus. The $F_{\text {IS }}$ was not estimated for this species due to the low number of alleles observed per fish.

- Umbrina cirrosa: three markers did not amplify (Soc423, Soc428 and Soc593) and 3 were monomorphic (Soc 44, Soc140, Soc400). Four markers exhibited more than 3 alleles (Soc416, Soc35, Soc156 and Soc432). A new allele not reported in A. regius was observed for each marker. The four last markers showed a good capacity for amplification and also 1 to 3 alleles not observed in A. regius: Soc11 (3 new alleles), Soc410 (2 new alleles), Soc412 (1 new allele) and Soc592 (3 new alleles). The $F_{\text {IS }}$ values calculated for each marker indicated an excess of homozygotes for most of the markers (data not shown).

- Argyrosomus regius: the marker Soc416 amplified badly and the markers Soc 400 and Soc410 were monomorphic. These markers were not used in the genetic analysis of $A$. regius. One specimen collected in Mauritania identified as Pseudotolithus senegallus based on its genotype characteristics was discarded from the data analyses.

Overall, eleven of the fourteen red drum microsatellites used in this study proved useful for further genetic investigations in $A$. regius: Soc11, Soc140, Soc423, Soc428, Soc592, and Soc593 from panel 1; and Soc35, Soc44, Soc156, Soc412 and Soc432 from panel 2 .

\subsection{Genetic variability of $A$. regius}

The number of alleles per locus varied from 3 to 31 (Table 2). Soc593 and Soc156 exhibited the lowest number of alleles (3 and 4 respectively), and Soc11, Soc35, Soc44, Soc412 and Soc428 the highest $(14,31,17,24$, and 25, respectively).

The genetic characteristics $\left(H_{\mathrm{e}}, H_{\mathrm{obs}}, N A, F_{\mathrm{IS}}\right)$ and the number of fish genotyped in the twelve collection sites are presented in Table 3 (upper section). The mean number of alleles per site varied from 4.09 in T1 to 8.63 in M4, with a mean for all sites of $6.28 \pm 1.15$ (mean $\pm \mathrm{SD})$. $H_{\mathrm{obs}}$ within site for all markers varied from $0.47 \pm 0.28$ in $\mathrm{T} 1$ to $0.67 \pm 0.19$ in $\mathrm{M} 3$ and $H_{\exp }$ varied from $0.46 \pm 0.24$ in $\mathrm{T} 1$ to $0.65 \pm 0.20$ in M1.

Null alleles were only detected for the loci Soc44 in F1 and E1, Soc423 in T1 and E2 and Soc 412 in E1. Only the E1 $(p<0.001)$ and M4 $(p<0.05)$ collection sites showed departure of genotypic frequencies from the expectations of HWE equilibrium.

$F_{\text {ST }}$ pair-wise comparisons revealed no significant differences between: F1 and F2, Mauritanian sites (except between M3 and M4), S1 and P2 or between E1 and E2 (Table 4).

The genetic characteristics $\left(H_{\mathrm{e}}, H_{\mathrm{obs}}, N A, A R\right.$ and $\left.F_{\mathrm{IS}}\right)$ and the number of fish genotyped in the six collection sites are presented in Table 3 (lower section). The mean number of alleles per site varied from 4.09 in "Turkey" to 11.00 in "Mauritania", with a mean for all sites of $6.98 \pm 2.37$ (mean \pm SD). The allelic richness differed significantly between sites $(p<0.001)$ and varied from 4.09 to 8.72. It was highest for the sites in "Mauritania" and "SW Iberia", intermediate in "France" and "W Portugal" and the lowest in "Egypt" and "Turkey". $H_{\mathrm{e}}$ differed significantly between sites $(p>0.002)$, and within-site $H_{\mathrm{obs}}$ for all markers varied from $0.47 \pm 0.28$ in T1 to $0.64 \pm 0.20$ in $\mathrm{F}$, and $H_{\text {exp }}$ varied from $0.46 \pm 0.24$ in $\mathrm{T} 1$ to $0.65 \pm 0.20$ in M.

Heterozygote or homozygote excesses are given in Table 3 (lower section). When all markers were considered, only the Egyptian site showed a significant heterozygote deficiency. Null alleles were detected for Soc423 in Egypt and Turkey, for Soc11 in SW Iberia and for Soc44 in Egypt.

Highly significant $F_{\text {ST }}$ differentiations $(p<0.002)$ were observed between all 6 collection sites (Table 5, above the 
Table 2. Mean number of alleles per microsatellite marker $( \pm \mathrm{SD})$ scored in meagre Argyrosomus regius, law croaker Pseudotolithus senegallus and shi drum Umbrina cirrosa genotyped in this study, taking the red drum Sciaenops ocellatus genotyped by Saillant et al. (2009) as a reference. * marker not used for genotyping by Saillant et al. (2009).

\begin{tabular}{|c|c|c|c|c|}
\hline Microsatellites & $\begin{array}{l}\text { Argyrosomus } \\
\text { regius }\end{array}$ & $\begin{array}{c}\text { Pseudotolithus } \\
\text { senegallus }\end{array}$ & Umbrina cirrosa & $\begin{array}{c}\text { Sciaenops } \\
\text { ocellatus }\end{array}$ \\
\hline Soc11 & 14 & 3 & 7 & 10 \\
\hline Soc35 & 31 & - & 5 & $*$ \\
\hline Soc44 & 17 & 2 & 1 & 24 \\
\hline Soc140 & 6 & 1 & 1 & 4 \\
\hline Soc156 & 4 & 1 & 4 & 5 \\
\hline Soc412 & 24 & 3 & 5 & 25 \\
\hline Soc 423 & 6 & 3 & - & 18 \\
\hline Soc428 & 25 & - & - & 28 \\
\hline Soc 432 & 8 & 4 & 3 & 9 \\
\hline Soc592 & 7 & 1 & 7 & $*$ \\
\hline Soc593 & 3 & 2 & - & $*$ \\
\hline Number of fish sampled & 361 & 17 & 31 & 45 \\
\hline $\begin{array}{l}\text { Mean number of alleles } \\
\text { per locus for all markers }\end{array}$ & $13.2 \pm 9.7$ & $2.2 \pm 1.1$ & $4.1 \pm 2.4$ & $15.4 \pm 9.6$ \\
\hline $\begin{array}{l}\text { Mean number of alleles } \\
\text { per locus with only the } \\
\text { Saillant et al. (2009) } \\
\text { common markers }\end{array}$ & $13.2 \pm 9.7$ & $2.4 \pm 1.1$ & $3.5 \pm 2.3$ & $15.4 \pm 9.6$ \\
\hline
\end{tabular}

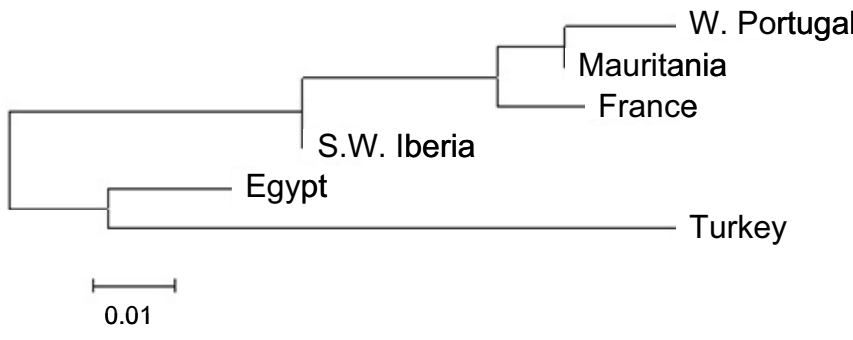

Fig. 2. Evolutionary relationships of the six Argyrosomus regius populations. The optimal tree is inferred by Neighbour-Joining with a sum of branch length. The tree is drawn to scale, with branch lengths in the same units as those of the evolutionary distances used to infer the phylogenetic tree. Phylogenetic analyses were conducted in MEGA 4.

diagonal). The lowest $F_{\mathrm{ST}}$ values were found between the Atlantic samples (values from $0.012<F_{\mathrm{ST}}<0.041$ ). Differentiation was moderate between the "Egypt" sample and all other populations $\left(0.061<F_{\mathrm{ST}}<0.107\right)$. The highest $F_{\text {ST }}$ values were found between "Turkey" and all other sites $\left(0.081<F_{\mathrm{ST}}<0.168\right)$, the highest of these being observed between "Turkey" and "W Portugal". Within the Mediterranean, despite a relative geographical proximity, high genetic differentiation was also observed between the two samples from "Egypt" and "Turkey" (0.081). The phylogenetic tree (Fig. 2) illustrates the subdivision of $A$. regius populations into two distinct groups between Atlantic and Mediterranean.

Estimates of effective population size $(\mathrm{Ne})$ are given in Table 6. Upper $\mathrm{Ne}$ values could not be differentiated from infinity (under the $95 \%$ confidence interval) for the populations from France, W Portugal and SW Iberia. The population from Mauritania showed a more limited $\mathrm{Ne}$ value of 111.0
$(61.6<N e<330.3)$. Only the population from Turkey presented a very low $\mathrm{Ne}$ of $17.4(10.3<\mathrm{Ne}<$ and 33.6).

\section{Discussion}

\subsection{Genetic structuring}

Genetic characterisation was made with microsatellite markers isolated from another species. The very limited number of null alleles in A. regius confirms the potential for cross-amplification between Sciaenids (Turner et al. 1998) and ability to identify $U$. cirrosa and $P$. senegallus species. Incidentally, A. regius presents a lower mean number of alleles per locus per population than the red drum (Saillant et al. 2009).

The non significant $F_{\text {ST }}$ values between different collection sites justified their pooling into six distinct new sites. Among the Mauritanian sites, a sampling artefact can be suspected for sample M4, as it is differentiated from one Mauritanian sample but not the other two. A hierarchical analysis of molecular variance could have been performed to account for regions and collection sites within regions, but we estimated that genetic differentiation was so high that any type of statistical method would give the same kind of results. Similarly, we did not estimate the effect of geographic distance on genetic differentiation since the geographic distances between sites are so great and different that this effect is obvious.

A. regius can be divided into at least two very distant genetic groups: Atlantic and Mediterranean. Our results reveal the existence of a previously unknown sixth distinct reproductive area for the species in the Aegean Sea, at the mouth of the Menderes river delta in Turkey. Interestingly, the SW Iberia population is somewhat intermediate between the Atlantic and Mediterranean, which is in accord with its geographical location. Reproduction has been also suggested in Morocco 


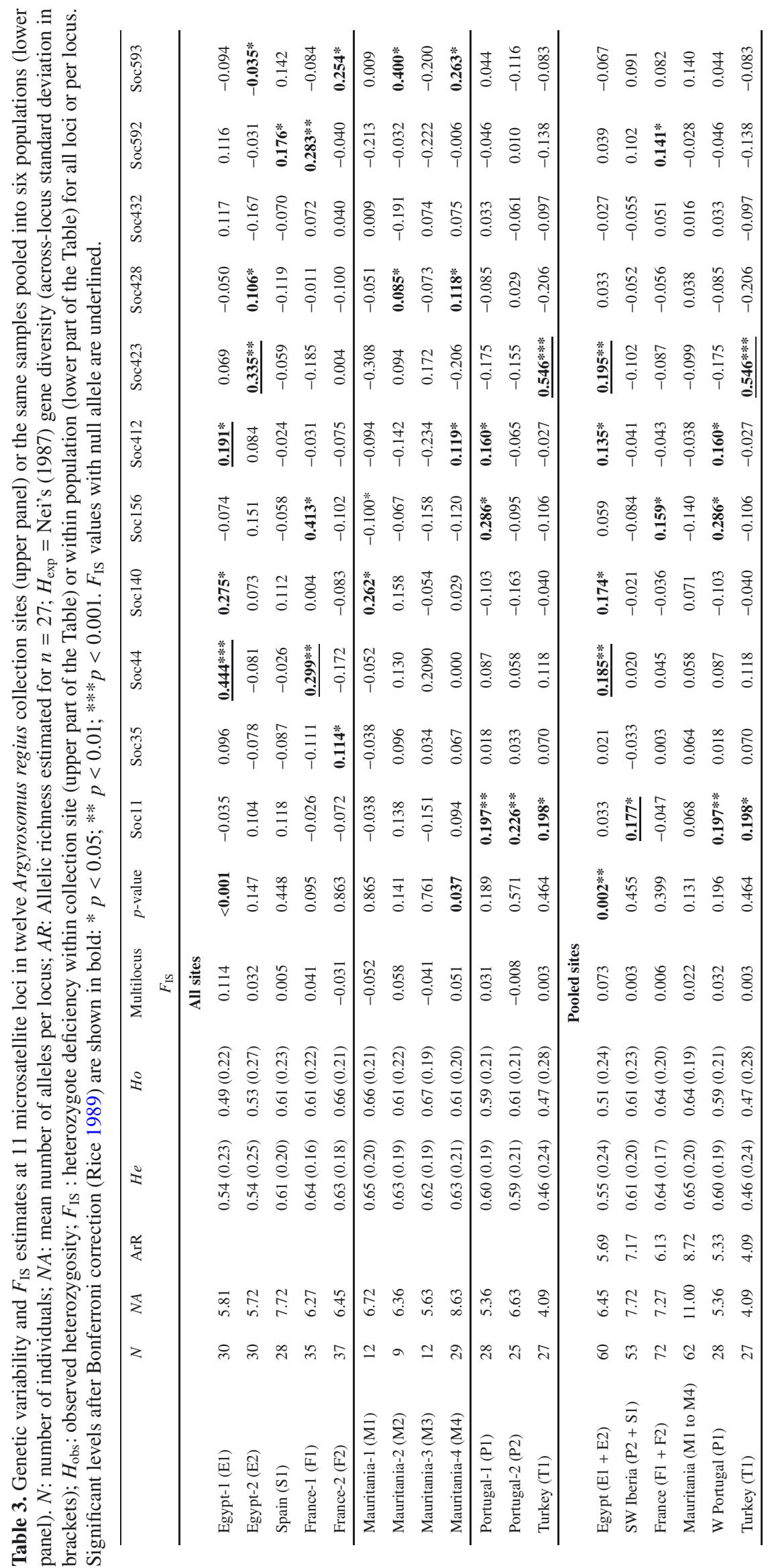


Table 4. Pair-wise estimates of $F_{\mathrm{ST}}$ values among the twelve Argyrosomus regius collection sites: Weir and Cockerham (1984) $\theta$-statistics above the diagonal and significance below the diagonal after simple Bonferroni correction (Rice 1989).

\begin{tabular}{|c|c|c|c|c|c|c|c|c|c|c|c|c|}
\hline & $\begin{array}{c}\text { France-1 } \\
(\mathrm{F} 1)\end{array}$ & $\begin{array}{c}\text { France-2 } \\
(\mathrm{F} 2)\end{array}$ & $\begin{array}{l}\text { Portugal-1 } \\
\text { (P1) }\end{array}$ & $\begin{array}{l}\text { Portugal-2 } \\
\text { (P2) }\end{array}$ & $\begin{array}{l}\text { Spain } \\
\text { (S1) }\end{array}$ & $\begin{array}{l}\text { Mauritania-1 } \\
\text { (M1) }\end{array}$ & $\begin{array}{l}\text { Mauritania-2 } \\
\text { (M2) }\end{array}$ & $\begin{array}{l}\text { Mauritania-3 } \\
\text { (M3) }\end{array}$ & $\begin{array}{l}\text { Mauritania-4 } \\
\text { (M4) }\end{array}$ & $\begin{array}{l}\text { Egypt-1 } \\
\text { (E1) }\end{array}$ & $\begin{array}{c}\text { Egypt-2 } \\
\text { (E2) }\end{array}$ & $\begin{array}{c}\text { Turkey } \\
\text { (T1) }\end{array}$ \\
\hline France-1 (F1) & & 0.003 & 0.021 & 0.023 & 0.035 & 0.021 & 0.026 & 0.033 & 0.038 & 0.112 & 0.108 & 0.159 \\
\hline France-2 (F2) & 0.186 & & 0.033 & 0.020 & 0.033 & 0.019 & 0.024 & 0.029 & 0.038 & 0.090 & 0.089 & 0.137 \\
\hline Portugal -1 (P1) & 0.004 & $<0.001$ & & $0.015^{*}$ & 0.014 & 0.044 & 0.019 & 0.044 & 0.034 & 0.109 & 0.011 & 0.168 \\
\hline Portugal.-2 (P2) & 0.002 & $<0.001$ & $<0.011$ & & 0.008 & 0.019 & 0.019 & 0.038 & 0.025 & 0.062 & 0.055 & 0.119 \\
\hline Spain (S1) & $<0.001$ & $<0.001$ & $<0.011$ & 0.076 & & 0.034 & 0.030 & 0.039 & 0.039 & 0.096 & 0.081 & 0.146 \\
\hline Mauritania-1 (M1) & 0.019 & 0.009 & $<0.001$ & 0.017 & 0.002 & & 0.007 & 0.001 & 0.006 & 0.068 & 0.065 & 0.113 \\
\hline Mauritania-2 (M2) & 0.016 . & 0.009 & 0.005 & 0.039 & 0.006 & 0.693 & & 0.023 & 0.009 & 0.057 & 0.061 & 0.118 \\
\hline Mauritania-3 (M3) & 0.008 & $<0.001$ & $<0.001$ & $<0.001$ & $<0.001$ & 0.449 & 0.053 & & 0.042 & 0.093 & 0.079 & 0.126 \\
\hline Mauritania-4 (M4) & $<0.001$ & $<0.001$ & $<0.001$ & $<0.001$ & $<0.001$ & 0.169 & 0.874 & 0.002 & & 0.063 & 0.065 & 0.115 \\
\hline Egypt-1 (E1) & $<0.001$ & $<0.001$ & $<0.001$ & $<0.001$ & $<0.001$ & $<0.001$ & $<0.001$ & $<0.001$ & $<0.001$ & & 0.001 & 0.093 \\
\hline Egypt-2 (E2) & $<0.001$ & $<0.001$ & $<0.001$ & $<0.001$ & $<0.001$ & $<0.001$ & $<0.001$ & $<0.001$ & $<0.001$ & 0.506 & & 0.075 \\
\hline Turkey (T1) & $<0.001$ & $<0.001$ & $<0.001$ & $<0.001$ & $<0.001$ & $<0.001$ & $<0.001$ & $<0.001$ & $<0.001$ & $<0.001$ & $<0.001$ & \\
\hline
\end{tabular}

Table 5. Pair-wise estimates of $F_{\mathrm{ST}}$ values among the six Argyrosomus regius populations: Weir and Cockerham (1984) $\theta$-statistics above the diagonal and significance below the diagonal after simple Bonferroni correction (Rice 1989).

\begin{tabular}{lrrrrrr}
\hline \multicolumn{1}{c}{ Samples } & France & W Portugal & Mauritania & SW Iberia & Egypt & Turkey \\
\hline France & & 0.026 & 0.026 & 0.025 & 0.099 & 0.140 \\
W Portugal & $<0.001$ & & 0.041 & 0.012 & 0.107 & 0.168 \\
Mauritania & $<0.001$ & $<0.001$ & & 0.024 & 0.061 & 0.098 \\
SW Iberia & 0.003 & $<0.001$ & $<0.001$ & & 0.073 & 0.126 \\
Egypt & $<0.001$ & $<0.001$ & $<0.001$ & $<0.001$ & & 0.081 \\
Turkey & $<0.001$ & $<0.001$ & $<0.001$ & $<0.001$ & $<0.001$ & \\
\hline
\end{tabular}

Table 6. Effective population size (Ne) estimates for the six Argyrosomus regius populations based on linkage disequilibrium estimated with parametric and jackknife methods (Waples and Do 2008). Ne: mean effective population size, upper and lower 95\% confidence interval are shown. * Negative value, estimated by the $L D N e$ software, suggests $N e$ is not different from infinity.

\begin{tabular}{lcrrrrr}
\hline \multirow{2}{*}{ Samples } & \multirow{2}{*}{$N e$} & \multicolumn{2}{c}{ Parametric method } & & \multicolumn{2}{c}{ Jackknife method } \\
& & Lower & Upper & & Lower & Upper \\
\cline { 1 - 4 } \cline { 6 - 7 } France & $-634.1^{*}$ & 394.1 & Large & & 281.3 & Large \\
W Portugal & $-117.5^{*}$ & 250.2 & Large & & 136.0 & Large \\
SW Iberia & $-722.1^{*}$ & 182.5 & Large & & 99.3 & Large \\
Mauritania & 111.0 & 68.7 & 237.2 & & 61.6 & 330.3 \\
Egypt & 531.5 & 292.3 & Large & & 151.6 & Large \\
Turkey & 17.4 & 10.7 & 31.8 & & 10.3 & 33.6 \\
\hline
\end{tabular}

(Hermas 1995) and in several other cryptic areas (Costa pers. comm.; Champagnat and Domain 1978; Dieuzeide 1929; Chakroum et al. 1983; Quéro 1989b).

\subsection{Why such high genetic differentiation?}

A. regius $F_{\mathrm{ST}}$ values are very high and in the highest ever reported in marine fish from this the same geographic area (Bonhomme et al. 2002; Nielsen et al. 2003, 2004; Alarcón et al. 2004; Kotoulas et al. 2006; Maggio et al. 2009; Gallarza et al. 2009; González-Wangüemert et al. 2010) or in smaller Sciaenids (Lankford et al. 1999; Gold et al. 2001; Ward et al. 2007; Han et al. 2008; Xiao et al. 2009). Such $F_{\text {ST }}$ values have only been previously reported for coastal marine species strongly affected by post-glacial recolonization (Wilson and Veraguth 2010) or for populations separated by the Atlantic ocean (Ball et al. 2007) or by the Indian Ocean for another Argyrosomus species, the mulloway A. japonicus (Archangi 2008).

Geographic and hydrological barriers were advocated to explain genetic differentiation in marine fish. The Cape Sagres separates the two Portuguese populations, which are less than $200 \mathrm{~km}$ apart. The Gibraltar Strait-Alboran Sea zone and the Siculo-Tunisian Strait limit genetic exchanges between the Atlantic Ocean and the southeast Mediterranean Sea (see Naciri et al. 1999; Barhi-Sfar et al. 2000; Patarnello et al. 2007). In the northern waters of the Aegean Sea, the lowest salinity and the coolest temperature induce a cyclonic circulation, causing its isolation from Egypt (Barhi-Sfar et al. 2000). These barriers may have played an important role in the recent past of the species.

The subdivision into the two Atlantic and Mediterranean groups and the lower allelic richness and effective sizes of the Mediterranean populations could be due to the effects of vicariance, limited introgression after secondary contact, and/or population expansion following the successive coolings and warmings of the Mediterranean Sea during previous interglacial phases of the Quaternary (Borsa et al. 1997; Bianchi and Morri 2000; Patarnello et al. 2007). Even though the present results do not demonstrate the impact of Pleistocene glaciation per se, these glaciations could have also restricted A. regius area in the Atlantic to a more southern part than its 
present distribution. Crowley (1981) estimates very low summer temperature $\left(9.2^{\circ} \mathrm{C}\right)$ in northern Portuguese waters at the time of the 18000 -year B.P. during the last glacial maximum. Such a low temperature makes the reproduction of $A$. regius in the Tagus and the Gironde estuaries theoretically impossible at this time. These northern populations could, therefore, result from a recent expansion in the North Atlantic Ocean, which is in agreement with their lower allelic richness. In the Atlantic, this result confirms the early Tixerant (1974) hypothesis of differentiation between France and Mauritania based on differential otolith growth. In the Mediterranean Sea, the genetic differentiation between the two populations is in agreement with the two biogeographic areas defined by Bianchi and Morri (2000) as "North Aegean" and "Gulf of Gabes to Levant Sea".

Biological factors have also been put forward to explain the genetic differentiation of marine organisms. However, early life-history traits (egg type, pelagic larval duration, and inshore-offshore spawning) have a limited involvement in the genetic differentiation of marine fishes (Gallarza et al. 2009). For A. regius, Tixerant (1974) and Quéro (1989a) pointed out factors that varied between Mauritania, Egypt and France, such as the difference in water salinity. They also identified differences in the duration and the time of reproduction (3 weeks in early June in the Gironde, the 2 months of February and March in Egypt, and 9 months from October to June in Mauritania). But among all the biological factors, reproductive migration is probably the most important factor limiting adult movement and, therefore, limiting gene flow between reproductive areas. This factor is reinforced by two others. The first is the limited number of potentially favourable sites for A. regius reproduction and for long term settlement. The need for an actual estuary was questioned by Tixerant (1974), as there is no estuary in Mauritania. A site favourable for reproduction would require intermediate temperature $\left(14{ }^{\circ} \mathrm{C}\right.$ to $\left.23{ }^{\circ} \mathrm{C}\right)$, with an optimal window $\left(19^{\circ} \mathrm{C}\right.$ to $\left.21^{\circ} \mathrm{C}\right)$ for reproduction and successful larval recruitment (Quéro and Vayne 1987; Quéro 1989a), high water flow and minimal water depth for spawning $(>10-15 \mathrm{~m})$. The second requirement is the need for extensive mudflats (in the Atlantic) or lagoons (in the Mediterranean) habitats close to the reproduction sites to provide a suitable environment for larval recruitment and juvenile growth (Quéro and Wayne 1987). The Gironde, Tagus, Guadalquivir and Menderes estuaries, the sea areas at the opening of the Nile river delta and the large mudflats in the Banc d'Arguin in Mauritania fulfil these basic requirements.

\subsection{Potential biases}

In this study, temporal variation in allele frequencies may be confounded with spatial variation because samples were composed of very different age groups among and within sites. However, the magnitude of the divergence between regions is so large that some noise due to temporal genetic variation is unlikely to have a great impact on the observed patterns of population structure reported here.

Bias could potentially arise from rearing wild fish in captivity by artificial selection for survival even if we estimate genetic variability of neutral markers. Only the population from
Egypt had a significant heterozygote deficiency when all loci were considered. Inbreeding can be excluded, as heterozygote deficiency was not the case at all loci. As heterozygote deficiency was also estimated before the pooling of the two collection sites, Wahlund effect (presence of different genetic stocks in a single sample) seems improbable as such a hypothesis would imply that each of the two Egyptian stocks would have been composed of different origins in the same ratio. Assortative mating can also be excluded as A. regius is a mass spawner (Tixerant 1974). An effect of artificial selection during captivity would require a strong association between the potentially neutral loci and survival, which is unrealistic with the limited number of markers used. Only a more detailed investigation on wild captured cohorts among different Egyptians coastal lakes could allow conclusions about these factors. In any case, the heterozygote deficiency observed in the Egyptian samples does not interfere with the general conclusion that there is very high geographic differentiation.

\subsection{Effective population sizes}

The estimations of population size differ greatly: from infinity (France, W Portugal, SW Iberia) to very limited (Turkey). Several factors need to be considered for the interpretation of these results.

$\mathrm{Ne}$ estimates were obtained from populations composed of different age groups (W Portugal, SW Iberia and Mauritania), a single age group (Egypt, Turkey) or two age groups (France). If estimates in the former three populations represent approximations of $\mathrm{Ne}$ (effective size for the generation), the $\mathrm{Ne}$ estimates from the latter three populations most probably reflect $N_{\mathrm{b}}$ (effective number of breeders having produced the sample) than $N_{\mathrm{e}}$ (Waples 2005). It can then be argued that the assumption of the statistical models based on discrete generations is severely violated as A. regius reproduces with overlapping generations until fourty years of age.

The long generation interval and overlapping generations are also factors that could cause genetic disequilibrium between age groups and underestimation of the true effective number of parents ("sweepstake recruitment hypothesis", Hedgecock 1994). Preliminary results from F1 and F2 yearly cohorts do not provide much if any support for this hypothesis as the two cohorts collected from the same population exhibited neither genetic differentiation nor heterozygote deficiency (caused in this case by temporal Wahlund effect).

High temporal heterogeneity in effective population size was also associated with a very low ratio of individuals producing new young fish to adult census population size in another large Sciaenid, the red drum Scianops ocellatus (Turner et al. 2002). The high variation in A. regius captures (i.e. from $350 \mathrm{t}$ in 1992 to $12200 \mathrm{t}$ in 2001 in Mauritania or from $35 \mathrm{t}$ in 1985 to 1356 t in 2006 in France, FAO data) could also result and/or create unequal reproductive success and fluctuation in population size between cohorts (Hedrick 2005).

Finally, all populations show very limited lower bounds of effective size, inferior to 500 (Table 6), which is very low for a marine fish and may indicate a population risk for long term viability (Franklin and Frankham 1998). Among the six populations identified, Turkey and Mauritania had a finite upper 
estimate of $\mathrm{Ne}$ effective (33.6 or 330.3). For the population from Turkey, that is also the less variable and the more genetically differentiated, the actual small surface of the Menderes delta, and its shallow lagoons for the juvenile development, could explain the limited annual captures $(<50 \mathrm{t}$, Gamsiz K. pers. comm.). The Holocene sea-level variations (Ergin et al. 2007; Kazanci et al. 2009) are also factors that have greatly restricted the Menderes delta surface and potentially limited reproductive capacities and therefore $\mathrm{Ne}$. The high genetic variation of the population from Mauritania is opposite to its limited $\mathrm{Ne}$ estimate. Since the Mauritanian "sample" combined small numbers of fish collected at four locations, the $\mathrm{Ne}$ estimate could be biased downward by mixture disequilibria from a two-locus Wahlund effect (see discussion in 4.3. about $F_{\text {ST }}$ values and genetic differentiation between Mauritanian sites) and underestimate the real $\mathrm{Ne}$, which should be considered higher.

More generally, the meagre shared several biological factors with the ten other large Sciaenids already threatened and for which the protection of seasonal aggregation areas and nursery grounds was advocated (Cisneros-Mata et al. 1995; Sadovy and Cheung 2003; Liu and Sadovy de Mitcheson 2008). The limited values of $\mathrm{Ne}$ and the very long distances known between reproduction areas should be considered in the meagre management, as recent river water pollution, modification of water flow and overfishing at $1^{+}$year of age were reported as factors associated with decreases in meagre abundance (Bebars et al. 1996; Oczkowski and Nixon 2008; Kazanci et al. 2009; Sourget and Biais 2009; Morales-Nin et al. 2012).

\section{Conclusion}

This study provides the first genetic characterisation of $\mathrm{Ar}$ gyronomus regius across most of its natural range. The species is genetically highly structured, with a degree of differentiation rarely reported in a marine fish. The high genetic fragmentation highlights the genetic originality of each population and the need to consider their management regionally. This work also demonstrates the existence of a previously unknown reproductive area in the Aegean Sea. Future studies, including the genetic characterisation of fish from other areas (Morocco, Balearic Islands, etc.) or other cryptic populations using microsatellite markers or mtDNA could offer further insight about $A$. regius ecology, biodiversity and recent evolution. These data will be useful for its preservation and for its exploitation by fisheries and aquaculture.

Acknowledgements. This study would not have been possible without the work and support of numerous collaborators to which authors are indebted:

- In Mauritania, to the fishery controllers of the NIOF, Oumar Bocar Mbodj that take real attention for the organization of the sample collection, Meinatt Abderrahman, Dia Moussa Moctar and Gueye Abdu, for their personal investment in the sample collection and stimulating discussions; Dr. Le Douguet L. (PNBA), Dr. Ebaye Ould Sidina (PNBA), Dr. Lemhaba Ould Yarba (PNBA), Dr. Rue O. (PNBA), Dr. Araujo A. (FIBA) and
Bernardon M. (IUCN) for their interest in the project and their advice and information about $A$. regius biology, ecology and fisheries in Mauritania and in the Parc National du Banc d'Arguin (PNBA).

- In Egypt, to Dr. Fouda M. (Egyptian Environmental Agency, Cairo) and Dr. El Tayeb O.M. (Pharmacy Faculty, Cairo) for their interest to the project and their help in providing official authorization for collection of genetic resources.

- In Portugal, to Dr. Costa M.J. and Dr. Costa J.L. (Centro de Oceanografia, Lisboa, Portugal) and numerous commercial and recreational fishers for fruitful discussions on the ecology of $A$. regius in the Tagus and Mira estuaries and Algarve coast.

- In France, to Dr. Sontot A. (BRG/INRA) for her crucial help in facilitating implementation of official agreements for access to genetic resources based on future ABS agreements, Didier Gascuel (ENSAR) for his support in collecting samples from Mauritania, Marine Levadoux (Comité Interprofessionnel des Produits de l'Aquaculture - CIPA) for her support in the management of the project, and Sophie Cariou (Ferme Marine du Douhet) and Rémi Ricoux (Les Poissons du Soleil) to have provided biological samples.

This work was supported by the two hatcheries FMD and Les Poissons du Soleil, by the Bureau des Ressources génétiques from the French Ministry of Environment and Sustainable Development (MEDD) and by the European Union (FEP financial support, Collective Actions 3058-2008). Additional support for the collection of the Portuguese samples was provided by FCT grant BD/12550/2003 to N. Prista and research project CORV (DGPA-MARE: 22-05-01FDR-00036).

\section{References}

Alarcón J.A., Magoulas A., Georgakopoulos T., Zouros E., Alvarez M.C., 2004, Genetic comparison of wild and cultivated European populations of the gilthead sea bream (Sparus aurata). Aquaculture 230, 65-80.

Archangi B., 2008, Levels and patterns of genetic diversity in wild and cultured populations of mulloway (Argyrosomus japonicus) using mitochondrial DNA and microsatellites. Thesis, School of Natural Resources Sciences, Brisbane, Queensland University of Technology.

Ball A.O., Beal M.G., Chapman R.W., Sedberry G.R., 2007, Population structure of red porgy, Pagrus pagrus, in the Atlantic Ocean. Mar. Biol. 150, 1321-1332.

Bahri-Sfar L., Lemaire C., Ben Hassine O.K., Bonhomme F., 2000, Fragmentation of the sea bass populations in the western and eastern Mediterranean as revealed by microsatellites polymorphism. Proc. R. Soc. Lond. B 267, 929-935.

Bebars M.L., Lassere G., Lam Hoai T., 1997, Analyse des captures des pêcheries marines et lagunaires d'Egypte en liaison avec la construction de haut barrage d'Assouan. Oceanol. Acta 20, 421436.

Belkhir K., Borsa P., Goudet J., Chikhi L., Bonhomme F., 2004, Genetix v4.05. Logiciel sous Windows ${ }^{\mathrm{TM}}$ pour la génétique des populations. Laboratoire Génome et Populations, Univ. Montpellier 2, Montpellier.

Bianchi C.N., Morri C., 2000, Marine biodiversity of the Mediterranean Sea: situation, problems and prospects for future research. Mar. Pollut. Bull. 40, 367-376. 
Bonhomme F., Naciri M., Barhi-Sfa L., Lemaire C., 2002, Analyse comparée de la structure génétique de deux espèces de poissons marins apparentés et sympatriques Dicentrarchus labrax et Dicentrarchus punctatus. C.R. Biol. 325, 213-220.

Borsa P., Naciri M., Bahri M., Chikhi L., Garcia de Leon F.J., Kotoulas G., Bonhomme F., 1997, Zoogéographie infraspécifique de la mer Méditerranée : analyse des données génétiques populationnelles sur seize espèces atlantoméditerranéennes (poissons et invertébrés). Vie Milieu 47, 295-305.

Chakroun N., Ktari M.H., Kamoun M.N., 1982, Production de Sciaenidae (Poisson, Téléostéens) des côtes tunisiennes. Bull. Inst. Natl. Scient. Tech. Océanogr. Pêches, Salammbô 9, 121-126.

Champagnat C., Domain F., 1978, Migrations des poissons démersaux le long des côtes ouest-africaines de 10 à $24^{\circ}$ de latitude Nord. Cah. ORSTOM, Sér. Océanogr. 16, 239-261.

Cisneros-Mata M.A., Montemayor-López G., Román-Rodriguez M.J., 1995, Life history and conservation of Totoaba macdonaldi. Conserv. Biol. 9, 806-814.

Costa M.J., 1986, Les poissons de l'estuaire du Tage. Cybium 10, $57-75$.

Crowley T.J., 1981, Temperature and circulation changes in the eastern north Atlantic during the last 150,000 years: evidence from the planktonic foraminiferal record. Mar. Micropaleontol. 6, 97129.

Dieuzeide R., 1929, Les Sciaenidés des côtes algériennes. Bull. Stat. Aquic. Pêche Castiglione 1, 133-161.

El-Hehyawi M.L.E., 1974, Changes in salinity and landing of six fish species in the shelf, North to the Nile Delta. Bull. Inst. Ocean. Fish. Cairo, 437-458.

Ergin M., Kadir S., Keskin S., Turhan-Akyüz N., Yaşar D., 2007, Late Quaternary climate and sea-level changes recorded in the sediment composition off the Büyük Menderes river delta (eastern Aegean Sea, Turkey). Quat. Int. 167-176.

Franklin I.R., Frankham R., 1998, How large must populations be to retain evolutionary potential? Anim. Conserv. 1, 69-73.

Galarza J.A., Carreras-Carbonell J., Macpherson E., Pascual M., Roques S., Turner G.F., Rico C., 2009, The influence of oceanographic fronts and early-life-history traits on connectivity among littoral fish species. Proc. Natl. Acad. Sci. 106, 1473-1478.

Gold J.R., Burridge C.P., Turner T.F., 2001, A modified steppingstone model of population structure in red drum. Sciaenops ocellatus (Sciaenidae), from the northern Gulf of Mexico. Genetica $111,305-317$.

González-Wangüemert M., Cánovas F., Pérez-Ruzafa A., Marcos C., Alexandrino P., 2010, Connectivity patterns inferred from the genetic structure of white seabream (Diplodus sargus L.). J. Exp. Mar. Biol. Ecol. 383, 23-31.

González-Quirós R., del Árbol J., García-Pacheco M.M., SilvaGarcía A.J., Naranjo J.M. Morales-Nin B., 2011, Life-history of the meagre Argyrosomus regius in the Gulf of Cadiz (SW Iberian Peninsula). Fish. Res. 109, 140-149.

Goudet J., 1995, Fstat version 1.2: a computer program to calculate Fstatistics. J. Hered. 86, 485-486.

Gyllensten U., 1985, The genetic structure of fish: differences in intraspecific distribution of biochemical genetic variation between marine, anadromous and freshwater species. J. Fish Biol. 26, 691-699.

Han Z.Q., Gao T.X., Zhuang Z., Tang Q.H., 2008, Genetic variation among white croaker populations. J. Ocean, Univ. China 7 , $72-76$.
Hedgecock D., 1994, Does variance in reproductive success limit effective population sizes of marine organisms? In: Beaumont A.R. (ed.), Genetics and evolution of aquatic organisms, Chapman and Hall, London, pp. 122-134.

Hedrick P.W., 2005, Large variance in reproductive success and the $\mathrm{Ne} / \mathrm{N}$ ratio. Evolution 59, 1596-1599.

Hermas J., 1995, Contribution à l'étude la biologie du maigre Argyrosomus regius (Asso, 1801) débarqué au port d'Agadir. Univ. Ibnou Zohr, Faculté des Sciences Agadir, Thesis.

Kazanci N., Dündar S., Alçicek M.C., Gürbüz A., 2009, Quaternary deposit of the Büyük Menderes Braben in western Anatolia, Turkey: Implication for river capture and the longest Holocene estuary in the Aegean Sea. Mar. Geol. 264, 165-176.

Kotoulas G., Mejuto J., Antoniou A., Kasapidis P., Tserpes G., Piccinetti C., Peristeraki P., García-Cortés B., Oikonomaki K., de la Serna J.M., Magoulas A., 2006, Global genetic structure of the swordfish (Xiphias gladius) as revealed by microsatellites DNA markers. Col. Vol. Sci. Pap. ICCAT, 61, 79-88.

Lankford T.E., Targett T.E., Gaffney P.M., 1999, Mitochondrial analysis of populations structure in Micropogonias undulates (Perciform, Sciaenidae). Fish. Bull. 97, 884-990.

Liu M., Sadovy de Mitcheson Y., 2008, Profile of a fishery collapse: why mariculture failed to save the large yellow croaker. Fish Fish. 9, 219-242.

Maggio T., Lo Brutto S., Garoia F., Tinti F., Arculeo M., 2009, Microsatellite analysis of red mullet Mullus barbatus (Perciformes, Mullidae) reveals the isolation of the Adriatic Basin in the Mediterranean Sea. ICES J. Mar. Sci. 66, 1883-1891.

Morales-Nin B., Geffen A.J., Pérez-Mayol S., Palmer M., GonzálezQuirós R., Grau A., 2012, Seasonal and ontogenic migrations of the meagre (Argyrosomus regius) determined by otolith geochemical signatures. Fish. Res. 127-128, 154-155.

Naciri M., Lemaire C., Borsa P., Bonhomme F., 1999, Genetic study of the Atlantic/Mediterranean transition in sea bass (Dicentrarchus labrax). J. Hered. 90, 591-596.

Nei M., 1978, Estimation of average heretozygosity and genetic distance from a small number of individuals. Genetics 89, 583-590.

Nielsen E.E., Hansen M.M., Ruzzante D.E., Meldrup D., Grønkjær P., 2003, Evidence of a hybrid-zone in Atlantic cod (Gadus morhua) in the Baltic and the Danish Belt Sea, revealed by individual admixture analysis. Mol. Ecol. 12, 1497-1508.

Nielsen E.E., Hemmer-Hansen J., Meldrup D., Hansen M.M., 2004, Genetic population structure of turbot (Scophthalmus maximus L.) supports the presence of multiple hybrid zones for marine fishes in the transition zone between the Baltic Sea and the North Sea. Mol. Ecol. 13, 585-595.

Oczkowski A., Nixon S., 2008, Increasing nutrient concentrations and the rise and fall of coastal fishery; a review of data from the Nile Delta, Egypt. Estuar. Coast. Shelf Sci. 77, 309-319.

Patarnello T., Volkaert F.A.M.J., Castilho R., 2007, Pillars of Hercules: is the Atlantic-Mediterranean transition a phylogeographical break? Mol. Ecol. 16, 4426-4444.

Prista N., Costa J.L., Costa M.J., Jones C.M., 2009, Age determination in meagre Argyrosomus regius. In: Ruano F., Campos A., Batista I., Falcão M., Brohueira M.J., Martins M.M., Martins R. (eds.), Relat. Cient. Téc. Inst. Invest. Pescas Mar. IPIMAR, Lisboa, Ser. Digital, 49.

Quéro J.C., Vayne J.J., 1987, Le maigre, Argyrosomus regius (Asso 1801) (Pisces, Perciforme, Sciaenidae) du golfe de Gascogne et 
des eaux plus septentrionales. Rev. Trav. Inst. Pêches Marit. 49, $35-66$.

Quéro J.C., 1989a, Sur la piste des maigres Argyrosomus regius (Poisson, Sciaenidae) du golfe de Gascogne et de Mauritanie. Océanis 15, 161-179.

Quéro J.C., 1989b, Le maigre Argyrosomus regius (Asso 1801) (Poisson, Perciforme, Sciaenidae) en Méditerranée occidentale. Bull. Soc. Zool. France 114, 81-89.

Renshaw M.A., Saillant E., Bradfield C.S., Gold J., 2006 , Microsatellite multiplex panels for genetic studies of three species of marine fishes: red drum (Scianops ocellatus), red snapper (Lutjanus campechanus), and cobia (Rachycentron canadum). Aquaculture 253, 731-735.

Rice W.R., 1989, Analyzing tables of statistical tests. Evolution 43, 223-225.

Ruzzante D.E., 1997, A comparison of several measures of genetic distance and population structure with microsatellite data: bias and sampling variance. Can. J. Fish. Aquat. Sci. 55, 1-14.

Sadek S., Sabry A.M., Asfoor S.M., 2009, Meagre, a new candidate in Egyptian aquaculture. Aquac. Eur. 34, 13-17.

Sadovy Y., Cheung W.L., 2003, Near extinction of a highly fecund fish: the one that nearly got away. Fish Fish. 4, 86-99.

Saillant E., Renshaw M.A., Gatlin III D.M., Neill W.H., Vega R.R., Gold J.R., 2009, An experimental assessment of genetic tagging and founder representation in hatchery-reared red drum (Sciaenops ocellatus) used in stock enhancement. J. Appl. Ichthyol. 25, 108-113.

Saitou N., Nei M., 1987, The neighbor-joining method: a new method for reconstructing phylogenetic trees. Mol. Biol. Evol. 4, 406-425.

Sourget Q., Biais G., 2009, Ecologie, biologie et exploitation du maigre du golfe de Gascogne. Rapp. final convention SMIDDESTIFREMER-CNRS.

Tamura K., Dudley J., Nei M., Kumar S., 2007, MEGA4: Molecular Evolutionary Genetics Analysis (MEGA) software version 4.0. Mol. Biol. Evol. 24, 1596-1599.
Tixerant G., 1974, Contribution à l'étude de la biologie du maigre ou courbine Argyrosomus regius (Asso 1801) (= Sciaena aquila Lacép.) sur la côte mauritanienne. Thèse Université, Univ. AixMarseille.

Turner T.F., Richardson L.R., Gold J.R., 1998, Polymorphic microsatellite DNA markers in red drum (Sciaenops ocellatus). Mol. Ecol. 7, 1771-1773.

Turner T.F., Wares J.P., Gold J.R., 2002, Genetic effective size is three orders of magnitude smaller than adult census size in an abundant, estuarine-dependent marine fish (Sciaenops ocellatus). Genetics 162, 1329-1339.

Van Oosterhout C., Hutchinson W.F., Derek P., Wills D.P.M., Shipley P., 2004, MICRO-CHECKER: software for identifying and correcting genotyping errors in microsatellite data. Mol. Ecol. Notes 4, 535-538.

Waples R.S., 2005, Genetic estimates of contemporary effective population size: to what time periods do the estimates apply? Mol. Ecol. 14, 3335-3352.

Waples R.S., Do C., 2008, LDNE: a program for estimating effective population size from data on linkage disequilibrium. Mol. Ecol. Res. 8, 753-756.

Ward R.D., Woodwark M., Skibinski D.O.F., 1994, A comparison of genetic diversity levels in marine, freshwater and anadromous fishes. J. Fish Biol. 44, 213-232.

Ward R.D., Bowers K., Hensley R., Mobley B., Belouski E., 2007, Genetic variability in spotted seatrout (Cynoscion nebulosus), determined with microsatellite DNA markers Fish. Bull. 105-197.

Weir B.S., Cockerham C.C., 1984, Estimating F-statistics for the analysis of population structure. Evolution 38, 1358-1370.

Wilson A.B., Veraguth I.E., 2010, The impact of Pleistocene glaciation across the range of a widespread European coastal species. Mol. Ecol. 19, 4535-4553.

Xiao Y., Zhang Y., Gao K., Yanagimoto T., Yabe M., Sakurai Y., 2009 , Genetic diversity in the mtDNA control region and population structure in the small yellow croaker Larimichthys polyactis. Environ. Biol. Fishes 85, 303-314. 